\title{
Effects of floral therapy on labor and birth: a randomized clinical trial
}

\author{
Efeitos da terapia floral no trabalho de parto e nascimento: ensaio clínico randomizado \\ Efectos de la terapia floral en el trabajo de parto y el nacimiento: ensayo clínico aleatorizado
}

Sonia Regina Godinho de Lara' ORCID: 0000-0001-7236-0273

Maria Cristina Gabrielloni' ORCID: 0000-0003-2395-9161

Mônica Bimbatti Nogueira Cesar ORCID: 0000-0001-5724-9315

Márcia Barbieri'

ORCID: 0000-0002-4662-1983

'Universidade Federal de São Paulo. São Paulo, São Paulo, Brazil.

How to cite this article: Lara SRG, Gabrielloni MC, Cesar MBN, Barbieri M. Effects of floral therapy on labor and birth: a randomized clinical trial. Rev Bras Enferm. 2021;74(Suppl 6):e20210079. https://doi.org/10.1590/0034-7167-2021-0079

\section{Corresponding author:}

Sonia Regina Godinho de Lara

E-mail: soniarglara@gmail.com

EDITOR IN CHIEF: Antonio José de Almeida Filho ASSOCIATE EDITOR: Priscilla Valladares Broca

Submission: 03-15-2021 Approval: 04-30-202

\begin{abstract}
Objectives: to assess the effects of floral therapy in the face of factors that boost pain in the parturition process and its results in the duration of labor. Methods: this is a randomized, controlled and triple-blind clinical trial. We selected 164 pregnant women with gestational age $\geq 37$ weeks, cervical dilation $\geq 4 \mathrm{~cm}$, randomly divided into floral therapy and placebo group. Results: the Five Flower floral essence proved to be effective, considering the factors that boost pain in labor. Experimental Group did not show an increase in contractions, unlike Control Group, which presented an increase of one contraction for mothers in active phase and amniorrhexis. The Five Flower essence proved to be effective in reducing labor time by 1:30h from the beginning of the intervention at birth. Conclusions: floral therapy proved to be effective in pain management, reflecting positively in its brevity, qualifying its outcome. Descriptors: Labor; Labor Pain; Floral Essences; Obstetric Nursing; Clinical Trial.
\end{abstract}

\section{RESUMO}

Objetivos: avaliar os efeitos da terapia floral frente aos fatores que potencializam a dor no processo de parturição e seus resultados na duração do trabalho de parto. Métodos: ensaio clínico randomizado, controlado e triplo-cego. Foram selecionadas 164 gestantes com idade gestacional $\geq 37$ semanas, dilatação cervical $\geq 4 \mathrm{~cm}$, divididas aleatoriamente em 2 grupos: terapia floral e placebo. Resultados: a essência floral Five Flower mostrou-se eficaz diante dos fatores que potencializam a dor no trabalho de parto. O Grupo Experimental não apresentou aumento das contrações, diferentemente do Grupo Controle, que apresentou aumento de uma (1) contração para as parturientes em fase ativa e bolsa rota. A essência Five Flower mostrou-se eficaz na redução de 1:30h do tempo do trabalho de parto do início da intervenção ao nascimento. Conclusões: o uso da terapia floral mostrou-se eficaz no controle da dor, refletindo positivamente na sua brevidade, qualificando seu desfecho. Descritores: Trabalho de Parto; Dor do Parto; Essências Florais; Enfermagem Obstétrica; Ensaio Clínico.

\section{RESUMEN}

Objetivos: evaluar los efectos de la terapia floral ante factores que potencian el dolor en el proceso del parto y sus resultados en la duración del parto. Métodos: ensayo clínico aleatorizado, controlado y triple ciego. 164 mujeres embarazadas con edad gestacional $\geq 37$ semanas, dilatación cervical $\geq 4 \mathrm{~cm}$, fueron divididas aleatoriamente en 2 grupos: terapia floral y placebo. Resultados: la esencia floral Five Flower demostró ser eficaz ante los factores que potencian el dolor en el parto. El Grupo Experimental no mostró un aumento de las, a diferencia del Grupo Control, que mostró un aumento de una (1) contracción para las parturientas en fase activa y bolsa rota. La esencia Five Flower demostró ser eficaz para reducir el tiempo de parto desde la 1: $30 \mathrm{~h}$ desde el inicio de la intervención hasta el nacimiento. Conclusiones: el uso de la terapia floral demostró ser eficaz en el control del dolor, reflejando positivamente su brevedad, calificando su resultado.

Descriptores: Trabajo de Parto; Dolor de Parto; Esencias Florales; Enfermería Obstétrica; Ensayo Clínico. 


\section{INTRODUCTION}

The Policy of Comprehensive Attention to Women's Health focuses on improving obstetric care. One of the points observed in the Program of Comprehensive Attention to Women's Health is the monitoring of pacts to reduce the rate of cesarean sections in hospitals of the Brazilian Unified Health System (SUS - Sistema Único de Saúde), rescuing the culture of the normal childbirth process as a natural childbirth, including it as the best choice, because it offers fewer risks to maternal and fetal health. In this sense, many other strands of research are present. One of them, of great significance for woman care, is that which deals with mother care in labor pain management ${ }^{(1-2)}$.

It is known that some factors, such as active phase of labor, rupture of the ovular membranes and induction, boost labor pain, leading mothers to enter a vicious Fear-Tension-Pain cycle $^{(2)}$.

The English obstetrician Grantly Dick-Read, in his work Childbirth Without Fear, became known worldwide for stating how the intense fear experienced by women in labor influenced the strong experience of pain. Its clarification on the Fear-Tension-Pain cycle experience, present in the birthing scene, contributes to today to the achievements of interventions of this triad, qualifying labor assistance ${ }^{(3)}$.

The use of non-pharmacological resources for pain relief during labor seeks to rescue the physiological character of the parturition process. Although it is widely recommended to be used in the obstetric care scenario, it is not routine in most services. This fact is explained, perhaps, due to the ignorance of such resources and their benefits both by professionals and by mothers ${ }^{(4-5)}$.

In this sense, it is up to nurse-midwives and other professionals who attend childbirth to promote care to reduce the factors that provide fear, tension and pain and possible unpreparedness faced by women, being able to use strategies that offer them comfort ${ }^{(6-7)}$.

It is in this context that floral therapy can be inserted as a nonpharmacological method for relieving tension and, consequently, fear and pain in labor. Considered Complementary Integrative Health Practice (CIPs), it is characterized by acting in the fields of disease prevention and health promotion, maintenance and recovery based on a model of humanized care and centered on individuals' comprehensiveness, comprehensive vision of health and non-invasive methods ${ }^{(8-9)}$.

Floral therapy is based on a concept in which cartesian division between body and mind is overcome by a perspective that integrates these elements in a dimension in which the mind assumes essential importance. Emotions alter the physical state due to the central nervous system, endocrine and immune system. Positive emotion establishes health, while the negative state stimulates diseases. Thus, the valorization of symptoms that are not only physical is necessary to solve problems that are not merely rooted in the biological field ${ }^{(10-11)}$.

A randomized placebo-controlled trial, which aimed to assess the efficacy of a Bach floral-based cream in signs and symptoms of carpal tunnel syndrome, concluded that could be an effective intervention in the management of this mild and moderate syndrome, reducing symptoms of severity, providing pain relief ${ }^{(12)}$.

A recent clinical study of intervention with floral therapy, which aimed to understand the experience of anxious obese individuals, showed the efficacy of therapy in reducing anxiety, feeling of tranquility and self-knowledge, which allowed self-control during feeding ${ }^{(13)}$.
Although scientific evidence shows the benefits of floral therapy, its use as a non-pharmacological method for pain relief in labor has not been described in scientific literature. One of the reasons is the lack of professionals who promote childbirth care and have experience with this type of complementary therapy. Professionals who effectively participate in labor assistance should have knowledge about CIPs in their training ${ }^{(14)}$.

Thinking about the triad that guide labor, fear-tension-pain, the Five Flower floral essence, Bach's emergency compound, is considered a combination of "rescue of emotional balance", due to its remarkable ability to deal with emergency situations of crisis and stress, a situation experienced by the mother in the active phase of labor ${ }^{15-16)}$.

\section{OBJECTIVES}

To assess the effects of floral therapy in the face of factors that boost pain in the parturition process and its results in the duration of labor.

\section{METHODS}

\section{Ethical aspects}

The study complied with the ethical requirements required, respecting the guidelines and regulatory standards of research with human beings. It is approved in the Brazilian Clinical Trials Registry (RBR-5tt55v).

\section{Study type, period and location}

This is an experimental, randomized, triple blind and controlled clinical trial led by CONSORT 2010 ${ }^{(17)}$, in which pre- and post-intervention design was used with repeated measurements between two groups. The allocation ratio used was 1:1, and masking applied occurred among the participants, the researcher and statistical team, responsible for data analysis. Data collection occurred between May and October 2018, from Monday to Sunday, during about ten hours a day, by two nurse-midwives specially trained for this purpose. It was performed in the in-hospital childbirth center for labor and childbirth care in a hospital linked to SUS of São Paulo State, Brazil.

\section{Sample, and inclusion and exclusion criteria}

Participants were mothers of habitual obstetric risk, with pregnancies that evolved uninterdermally, admitted to the inhospital childbirth center.

The sample size was calculated from a pilot study with 30 mothers. Maternal heart rate was used as a sizing variable.

The required sample was 74 mothers per group, totaling 148 women. However, due to probable losses, the sample calculation was expanded by $10 \%$, totaling 164 mothers, subdivided into two groups of 82 each, named even and odd, later revealed as control and experimental, respectively. Inclusion criteria were used: mothers with a minimum age of 18 years complete, full-term pregnancy between 37 weeks and 42 complete weeks, with a single fetus, alive in phletid cephalic presentation; free from any clinical and/or obstetric pathology; be in established labor, i.e., have two uterine contractions in ten minutes, cervical dilation of at least 4 
$\mathrm{cm}$ and maximum of $8 \mathrm{~cm}$ recorded in the childbirth. Exclusion criteria: mothers with indication of cesarean childbirth at the time of hospitalization; smokers; patients with mental disorders; have ingested caffeine in the last 10 hours; users of any psychoactive drug.

\section{Study variables}

The variables studied were stratified into sociodemographic and obstetric: age, color, education, marital status, occupation and family income, gestational age, number of pregnancies, abortions and parities, cervical dilation, frequency and intensity of uterine contractions, condition of the ovular membranes (intact or broken (amniorrhexis)).

\section{Study protocol}

Mothers were contacted in the prepartum room and assessed for obstetric risk and eligibility criteria through interviews, analysis of obstetric records and prenatal cards. None of the exclusion criteria and demonstrated good adherence to the interventions provided for by the Protocol. Those who met all inclusion criteria were invited to participate in the study. After acceptance, the Informed Consent Form was requested.

The interventions were identified in cards numbered from 1 to 164 randomly distributed, in which they corresponded to 164 different numbers. For group allocation, even or odd, each mother chose a card contained in brown envelope, whose number corresponded to the therapy received. Even numbers indicated the receipt of 4 drops of solution diluted in $20 \mathrm{ml}$ of water every 15 minutes, for one hour, in the previously manipulated bottle, registered and identified by the importer as a pair; the odd numbers indicated the receipt of 4 drops of diluted solution in $20 \mathrm{ml}$ of water every 15 minutes, for one hour, in the previously manipulated bottle, registered and identified by the importer as odd. Each number drawn was removed from the amount until the end of the formation of each study group, equivalent to two intervention groups. It is emphasized that the weaknesses that contained the solutions were externally identical, what differentiated them were the labels "Even","Odd", being not able to recognize which was floral or placebo.

The mothers were assessed before the intervention and 30 minutes after the last dose of droplet intake destined for randomization, totaling two hours ( $2 \mathrm{~h}$ ) between the first assessment and the second; this period was in accordance with the hospital's obstetric assessment standards.

\section{Analysis of results, and statistics}

Data were collected digitally using the data collection application adapted in Visual Basic Applications language, installed in a Dell notebook with a 15-inch screen and 1TB of capacity, which allowed the storage of information regarding the study variables.

The data collected in digital spreadsheet were automatically integrated into an Excel software database ${ }^{\circ}$, version 2016. For data analysis, the comparison of means between two groups was performed using Student's t-test for independent samples. In order to analyze the behavior of obstetric characteristics, generalized estimation equations (GHG) models were used. Additionally, multivariate analysis was used using the decision/classification tree using the CHAID (Chi Square Interaction Detector) algorithm.
For the time of the intervention until the moment of childbirth, the linear regression model was adjusted, which has as one of the assumptions data distribution normality, which was verified via the Kolmogorov-Smirnov test.

A significance level of $5 \%$ was utilized for all statistical tests. For other analyses, the statistical software Statistical Package for the Social Sciences (SPSS) 20.0 was used.

\section{RESULTS}

In the recruitment and allocation of the 170 eligible mothers, 06 were excluded before randomization by refusal. Thus, 164 mothers were randomized and randomly allocated into 2 groups of interventions divided preliminary into Even Group $(n=82)$ and Odd Group ( $\mathrm{n}=82$ ), named after data analysis as control and experimental, respectively.

In follow-up, after randomization, there were 08 losses, 05 in Control Group and 03 in Experimental Group, all by births before finishing the intervention.

In analysis, of the total of 164 mothers who started the research protocol, 156 completed all stages (Control Group $=77$, Experimental Group = 79).

Figure 1 presents the flow diagram of participants according to CONSORT 2010 (17).

There were no distinct distributions or difference of means of sociodemographic and obstetric characteristics by type of intervention (Table 1).

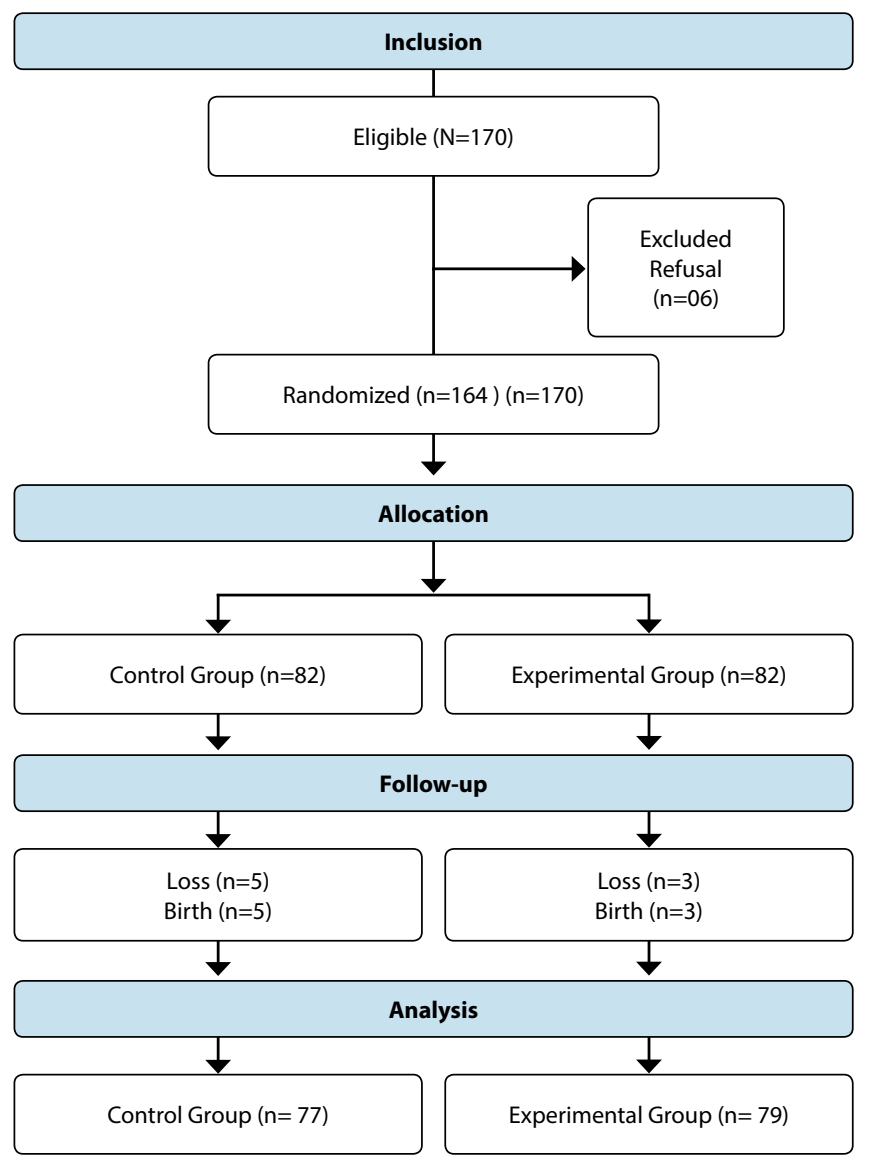

Figure 1 - Flow diagram of the study design and allocation of participants 
It was verified that the frequency of the initial uterine contraction of Experimental Group (2.7) was higher than that of Control Group (2.3), but after the intervention, there was an increase in the frequency of Control Group (2.8), causing the groups to become homogeneous. To better understand the increase in contraction in Control Group, the decision tree was used to explore the behavior of contraction variation by conditions that boost labor (type of amniotic membrane and pre-intervention cervical dilation) in both groups. The results found in the decision tree were presented in table form, for better visualization and understanding of the data (Table 3).
There are differences in means of the variation in the frequency of contraction by groups resulting from the decision tree $(p<0.001)$. Thus, it is observed that Experimental Group did not present differentiation by any of the characteristics. Control Group, with initial dilation of $5 \mathrm{~cm}$ or more and with rota pouch, verified an increase of one (1) contraction, with initial dilation of $5 \mathrm{~cm}$ or more and with intact amniotic membrane (0.582), being higher than the average of the entire Experimental Group (0.200) (Table 3).

The treatment presented significance of 0.076 , indicating a tendency to reduce the time to childbirth in about 1:30h (-85.51), adjusted by cervical dilation, frequency of initial contraction.

Table 1 - Sociodemographic and obstetric characteristics of mothers according to Intervention Group, São Paulo, São Paulo, Brazil, 2018, (n=156)

\begin{tabular}{|c|c|c|c|c|}
\hline Variables & Total $(n=156)$ & Experimental Group ( $n=79)$ & Control Group $(n=77)$ & $p$ \\
\hline Age (years) & & & & 0.192 \\
\hline Mean \pm SD & $25.0 \pm 5.6$ & $25.6 \pm 6.0$ & $24.4 \pm 5.0$ & \\
\hline Median (min. - max.) & $24(18-42)$ & $24(18-42)$ & $23(18-38)$ & \\
\hline Color, n (\%) & & & & $0.332^{\mathrm{a}}$ \\
\hline White & $42 / 156(26.9)$ & $17 / 79(21.5)$ & $25 / 77(32.5)$ & \\
\hline Black & $15 / 156(9.6)$ & $7 / 79(8.9)$ & $8 / 77(10.4)$ & \\
\hline Yellow & $7 / 156(4.5)$ & $5 / 79(6.3)$ & $2 / 77(2.6)$ & \\
\hline Brown & $92 / 156(59)$ & $50 / 79(63.3)$ & $42 / 77(54.5)$ & \\
\hline Education, n (\%) & & & & $0.836^{\mathrm{a}}$ \\
\hline 1 to 3 years & $1 / 156(0.6)$ & $1 / 79(1.3)$ & $0 / 77(0)$ & \\
\hline 4 to 7 years & $16 / 156(10.3)$ & $7 / 79(8.9)$ & 9/77 (11.7) & \\
\hline 8 to 11 years & $119 / 156(76.3)$ & $60 / 79(75.9)$ & $59 / 77(76.6)$ & \\
\hline 12 years or over & $20 / 156(12.8)$ & $11 / 79$ (13.9) & $9 / 77(11.7)$ & \\
\hline Marital status, n (\%) & & & & $0.508^{b}$ \\
\hline Single & $52 / 151(34.4)$ & 28/76 (36.8) & $24 / 75(32.0)$ & \\
\hline Married & $40 / 151(26.5)$ & $17 / 76(22.4)$ & $23 / 75$ (30.7) & \\
\hline Common-law marriage & $59 / 151(39.1)$ & $31 / 76(40.8)$ & $28 / 75(37.3)$ & \\
\hline Occupation, n (\%) & & & & $0.096^{b}$ \\
\hline Working & $63 / 156(40.4)$ & $37 / 79(46.8)$ & 26/77 (33.8) & \\
\hline Not working & 93/156 (59.6) & $42 / 79(53.2)$ & $51 / 77(66.2)$ & \\
\hline Family income, $\mathrm{n}(\%)$ & & & & $0.550^{\mathrm{a}}$ \\
\hline $1 \mathrm{MW}$ & 49/113 (43.4) & 26/63 (41.3) & $23 / 50(46)$ & \\
\hline Two MW & $44 / 113(38.9)$ & $25 / 63$ (39.7) & $19 / 50(38)$ & \\
\hline Three MW & $14 / 113(12.4)$ & $7 / 63(11.1)$ & $7 / 50(14)$ & \\
\hline Four MW & $6 / 133(5.3)$ & $5 / 63(11.1)$ & $1 / 50(14)$ & \\
\hline Gestational age (week) & & & & 0.086 \\
\hline Mean \pm SD & $39.3 \pm 1$ & $39.2 \pm 1.0$ & $39.4 \pm 1.0$ & \\
\hline Median (min. - max.) & $39(37-41)$ & $39(37-41)$ & $40(37-41)$ & \\
\hline Number of pregnancies & & & & 0.680 \\
\hline Mean \pm SD & $2.0 \pm 1.2$ & $2.0 \pm 1.1$ & $1.9 \pm 1.2$ & \\
\hline Median (min. - max.) & $2(0-6)$ & $2(1-6)$ & $1(0-5)$ & \\
\hline Number of deliveries & & & & 0.371 \\
\hline Mean \pm SD & $0.7 \pm 0.9$ & $0.8 \pm 0.9$ & $0.6 \pm 1.0$ & \\
\hline Median (min. - max.) & $0(0-4)$ & $1(0-3)$ & $0(0-4)$ & \\
\hline Number of abortions & & & & 0.352 \\
\hline Mean \pm SD & $0.3 \pm 0.6$ & $0.2 \pm 0.5$ & $0.3 \pm 0.6$ & \\
\hline Median (min - max.) & $0(0-3)$ & $0(0-2)$ & $0(0-3)$ & \\
\hline
\end{tabular}

Note: $M W$ - minimum wage; $p$ - descriptive level of Student's $t$-test, Fisher's exact (a) or chi-square (b); SD - standard deviation; Min. - minimum; Max. - maximum; $N=5$ and N=43 cases without information on marital status and income, respectively.

Table 2 - Obstetric characteristics of mothers by intervention group, São Paulo, São Paulo, Brazil, 2018, (n=156)

\begin{tabular}{|c|c|c|c|c|c|c|}
\hline \multirow[b]{2}{*}{ Variables } & \multicolumn{2}{|c|}{ Assessment time } & \multirow[b]{2}{*}{ Post-Pre } & \multirow[b]{2}{*}{ Intervention } & \multirow{2}{*}{$\begin{array}{c}p \\
\text { Time }\end{array}$} & \multirow[b]{2}{*}{$\begin{array}{c}\text { Interaction } \\
\text { Intervention x Time }\end{array}$} \\
\hline & Pre & Post & & & & \\
\hline Cervical dilation (cm) & & & & 0.346 & $<0.001$ & 0.930 \\
\hline Experimental Group & $4.9 \pm 0.9$ & $5.9 \pm 1.4$ & $1.0 \pm 1.1$ & & & \\
\hline Control Group & $5.1 \pm 1.0$ & $6.1 \pm 1.4$ & $1.0 \pm 0.8$ & & & \\
\hline Uterine contraction- frequency & & & & 0.031 & 0.059 & 0.057 \\
\hline Experimental Group & $2.7 \pm 1.0$ & $2.9 \pm 1.1$ & $0.2 \pm 1.0$ & & & \\
\hline Control Group & $2.3 \pm 1.0$ & $2.8 \pm 1.1$ & $0.5 \pm 1.0$ & & & \\
\hline
\end{tabular}




\begin{tabular}{|c|c|c|c|c|c|c|}
\hline \multirow[b]{2}{*}{ Variables } & \multicolumn{2}{|c|}{ Assessment time } & \multirow[b]{2}{*}{ Post-Pre } & \multirow[b]{2}{*}{ Intervention } & \multirow{2}{*}{$\begin{array}{c}\boldsymbol{p} \\
\text { Time }\end{array}$} & \multirow[b]{2}{*}{$\begin{array}{c}\text { Interaction } \\
\text { Intervention x Time }\end{array}$} \\
\hline & & Post & & & & \\
\hline Uterine contraction-duration (seconds) & & & & 0.873 & 0.007 & 0.188 \\
\hline Experimental Group & $31.7 \pm 12.1$ & $35.2 \pm 15.1$ & $3.5 \pm 11.6$ & & & \\
\hline Control Group & $31.4 \pm 11.2$ & $37.3 \pm 11.3$ & $5.8 \pm 11.2$ & & & \\
\hline
\end{tabular}

Table 3 - Summary measures of contraction frequency variation by intervention group, São Paulo, São Paulo, Brazil, 2018, (n=156)

\begin{tabular}{|c|c|c|c|c|c|c|c|}
\hline Group & Mean & Median & Standard Deviation & Minimum & Maximum & $\mathbf{N}$ & $p$ \\
\hline Groups & & & & & & & $<0.001$ \\
\hline Experimental Group & $0.200^{\mathrm{B}}$ & 0.000 & 0.966 & -1.000 & 4.000 & 79 & \\
\hline Control Group - dilation $=4 \mathrm{~cm}$ & $0.083^{B}$ & 0.000 & 0.929 & -2.000 & 2.000 & 24 & \\
\hline Control Group - dilation $\geq 5 \mathrm{~cm}$, amniorrhexis & $1.000^{\mathrm{A}}$ & 1.000 & 0.617 & 0.000 & 2.000 & 22 & \\
\hline Control Group - $\geq 5 \mathrm{~cm}$ dilation, intact membrane & 0.582 & 0.000 & 1.028 & -2.000 & 3.000 & 31 & \\
\hline
\end{tabular}

Note: $p$-descriptive level of Kruskal-Wallis test; $(A)$ and $(B)$ present distinct means according to multiple Dunn-Bonferroni comparations.

Table 4 - Result of linear regression model for time of intervention at birth, São Paulo, São Paulo, Brazil, 2018, (n=156)

\begin{tabular}{lcc}
\hline Characteristics & Coefficient & 95\% \\
\hline Experimental Group (ref.=Control Group) & -85.51 & -180.05 a 9.04 \\
$\quad$ Cervical dilation before (cm) & -94.27 & -142.04 a -46.5 \\
Contraction frequencies - before & 10.46 & -38.44 a 59.36 \\
Constant & 947.40 & 0.076 \\
\hline
\end{tabular}

Kolmogorov-Smirnov test for normal distribution ( $p=0.076)$.

\section{DISCUSSION}

Considering the results presented in this study, homogeneity was observed in mothers' sociodemographic and obstetric characteristics (Table 1).

In general, it was observed that $59.0 \%$ of mothers were brown, $76.3 \%$ had 8 to 11 years of schooling, $39.1 \%$ had a stable union, $59.6 \%$ did not work and $43.4 \%$ had an income of up to one minimum wage. Regarding obstetric characteristics, Experimental Group mothers had, on average, gestational age of 39 weeks and 2 pregnancies, those of Control Group, 40 weeks, and both groups had an average of 1.9 gestation (Table1)

Experimental Group mothers presented, before the intervention, on average, higher frequency of contraction. However, when assessing the frequency of contraction after the intervention, it was observed that this group presented frequency similar to Control Group, but the intensity of contraction of Control Group increased in relation to Experimental Group (Table 2).

In order to understand and assess the behavior of the frequency of contraction in relation to the factors that boost labor, in both groups, through the decision tree, it was possible to observe differences in the means of the variation by intervention group (Table 3).

In this case, Experimental Group did not present differentiation in the mean frequency of contraction in relation to the initial dilation equal to or greater than $5 \mathrm{~cm}$, type of ovular membrane and induction, i.e., there was no increase in contraction in the face of factors that boost labor, not altering the evolution of labor, qualifying the outcome of childbirth. However, the same did not happen with mothers in Control Group, who presented different frequencies in the active phase $(\geq 5 \mathrm{~cm})$ and in the occurrence of ruptured amniotic membranes, as they presented an increase in the mean frequency of one (1.0) count (Table 3).
These results corroborate Read's studies, in which the fear of labor gives rise to a protective tension, which is not only mental, but also influences muscle tension, which prevents the coordination of muscle contraction and, consequently, increased pain. This, in turn, increases tension by installing the vicious FearTension-Pain cycle. For this reason, Read argued that, in addition to mothers being anatomically perfect and chemically balanced, she should present emotionally well, remaining within a limit of normality, avoiding the onset of tension-producing reflexes that could hinder the birth process ${ }^{(3)}$.

A qualitative study, with the aim of describing the experience of women undergoing the use of flower essences as a non-pharmacological therapy for pain and anxiety relief during labor, carried out in a Normal Childbirth Center, it was observed that the use of flower essence provided, according to report of nurses who assisted them, calm, relaxation, concentration and courage to women, facilitating the process of birth ${ }^{(18)}$.

In this sense, it is believed that the Five Flower essence provided Experimental Group mothers with calm and relaxation, not allowing the Fear-Tension-Pain triad to interfere in the coordination of contractions, remaining constant in the face of boosting factors of labor, contributing, in a way, to a more physiological evolution of labor.

Regarding the time of the intervention at birth, adjusted by cervical dilation, frequency of contraction, it is noticed that Experimental Group had a reduction of about one hour and thirty minutes (1:30h) from the beginning of the intervention at birth, when compared to Control Group (Table 4).

Suffering, unlike pain, occurs when a woman is unable to activate her own coping mechanisms in relation to pain or when her own mechanisms are insufficient to deal with the situation, which can generate great stress. A study reveals that mothers 
who have stress, anxiety and fear can obtain as a result of this negative state the elevation of adrenaline and norepinephrine, leading to a decrease in the progression of labor ${ }^{(19-20)}$.

It is known that births are associated with high levels of cortisol in the umbilical cord blood of newborns. Increasing evidence shows that the stress experienced by the fetus or newborn may have long-term effects on the function of the hypothalamic-pituitary-adrenal axis in adulthood, cortisol and prolactin levels in umbilical cord blood, correlating positively with the duration of childbirth, i.e., the longer the duration of labor, the higher the level of cortisol in the umbilical cord blood of newborns ${ }^{(21)}$.

Considering the above, the advantages for the dyad in shortening the time of labor are beneficial. Our results show that the Five Flower floral essence provided Experimental Group mothers with level of consciousness that facilitated the physiological process of childbirth, activating its coping mechanisms in relation to pain, resulting in an emotional balance abbreviating the time of labor.

\section{Study limitations}

A limitation is the reduced number of clinical researches with the use of flower essences aimed at nursing-midwifery, restricting the analysis, comparison and interpretation of results.

\section{Contributions to nursing, health and public policies}

This is a pioneering study with the use of floral essences in women in labor, which reveals to be an effective integrative practice for providing emotional balance and, consequently, promoting the brevity of labor, reducing tension and relieving pain during the parturition process.

Such information and data may contribute to possible actions to improve protocols and improve obstetric care as well as become a reference for future research that deepens the analyses proposed here.

\section{CONCLUSIONS}

This study analyzed the effects of floral essences against the factors that boost labor pain and its results in the duration of labor.

Using the Five Flower floral essence provided emotional balance to the mothers, leading to constancy in the mean contraction, regardless of factors that boost labor, qualifying its outcome.

The Five Flower floral essence allowed mothers to relax through tension management and coping with fear, reflecting positively on the brevity of labor.

It was concluded that the Five Flower floral essence, which has as its main function the regate of physical and emotional balance, was effective in reducing tension and pain management, and can be used as a non-pharmacological method for pain relief in labor.

\section{REFERENCES}

1. Ayres LF, Henriques BD, Amorim WM. [The cultural representation of "natural childbirth": the outlook on the pregnant body in the midtwentieth century]. Ciên Saúde Colet [Internet]. 2018 [cited 2020 Jun 10];23(11):3525-34. Available from: https://www.scielo.br/pdf/csc/ v23n11/1413-8123-csc-23-11-3525.pdf Portuguese

2. Ministério da Saúde (BR). Secretaria de Ciência, Tecnologia e Insumos Estratégicos. Diretrizes nacionais de assistência ao parto normal. Brasília: Ministério da Saúde [Internet]. 2017 [cited 2020 Jun 10]. Available from: https://bvsms.saude.gov.br/bvs/publicacoes/diretrizes_ nacionais_assistencia_parto_normal.pdf

3. Dick-Read G. Childbirth without fear: the principles and practice of natural childbirth. New York: Harper and Row; 2013. 347 p.

4. Mielke KC, Gouveia HG, Gonçalves CA. The practical of non-pharmacological methods for relieving the pain of childbirth in a university hospital in Brazil. Av Enferm. 2019;37(1):47-55. https://doi.org/10.15446/av.enferm.v37n1.72045

5. Melo JK, Barroso ML, Alencar JS, Bandeira LA, Melo AM, Mesquita Neto E, et al. Cuidados e métodos não-farmacológicos de alívio da dor nas gestantes em trabalho de parto. Rev Mult Psicol. 2019;13(44):73-86. https://doi.org/10.14295/idonline.v13i44.1583

6. Gayeski ME, Brüggemann OM. Métodos não farmacológicos para alívio da dor no trabalho de parto: uma revisão sistemática. Texto Contexto Enferm. 2010;19(4):774-82. https://doi.org/10.1590/S0104-07072010000400022

7. Mafetoni RR, Rodrigues MH, Silva FM, Jacob LM, Shimo AK. Effectiveness of auricular therapy on labor pain: a randomized clinical trial. Texto Contexto Enferm. 2019;28:e20180110. https://doi.org/10.1590/1980-265x-tce-2018-0110

8. Azevedo LS, Fettermann FA, Bordignon J, Rosa AB, Costa S, Donaduzzi DS. Métodos não farmacológicos para o alívio da dor durante o trabalho de parto: vivências de enfermeiras obstétricas. Vivencias. 2020;16(30):115-2. https://doi.org/10.31512/vivencias.v16i30.118

9. Ministério da Saúde (BR). Portaria no 702 de 21 de março de 2018. Altera a Portaria de Consolidação n 2/GM/MS, de 28 de setembro de 2017, para incluir novas práticas na Política Nacional de Práticas Integrativas e Complementares - PNPIC. Brasília: Ministério da Saúde [Internet]. 2018 [cited 2020 Jul 10]. Available from: http://bvsms.saude.gov.br/bvs/saudelegis/gm/2018/prt0702_22_03_2018.html

10. Ribeiro JA, Araújo MH, Vieira ES, Maia AL, Costa DA, Sousa MS. Use of floral therapy in anxiety and stress. Braz J H Rev [Internet]. 2020;3(3):4404-12. https://doi.org/10.34119/bjhrv3n3-040

11. Araújo CL, Silva MJ, Bastos VD. Terapia floral: equilíbrio para as emoções em tempos de pandemia [Internet]. ObservaPICS; 2020 [cited 2020 Jul 10]. 14p. Available from: http://observapics.fiocruz.br/wp-content/uploads/2020/04/PDF-Florais-v7.pdf

12. Rivas-Suarez SR, Aguila-Vazquez J, Suarez-Rodriguez B, Vazquez-Leon L, Casanova-Giral M, Morales-Morales R, et al. Exploring the effectiveness of external use of Bach flower remedies on carpal tunnel syndrome: a pilot study. J Evid Based Complement Altern Med. 2017;22(1):18-24. https://doi.org/10.1177/2156587215610705 
13. Pancieri AP, Fusco SB, Ramos BI, Braga EM. Meanings of flower therapy for anxiety in people with overweight or obesity. Rev Bras Enferm. 2018;71(Suppl 5):2310-5. https://doi.org/10.1590/0034-7167-2018-0044

14. Kalder M, Knoblauch K, Hrgovic I, Münstedt K. Use of complementary and alternative medicine during pregnancy and delivery. Arch Gynecol Obstet. 2011;283(3):475-82. https://doi.org/10.1007/s00404-010-1388-2

15. Monari C. Participando da vida com os florais de Bach. 6a ed. São Paulo: Acallanto; 2018. 664 p.

16. Bach E. Os remédios florais do Dr. Bach. 19a ed. São Paulo: Pensamento; 2006. 112 p.

17. Schulz KF, Altman DG, Moher D, CONSORT Group. Withdrawn: CONSORT 2010 statement: updated guidelines for reporting parallel group randomised trials. Int J Surg. 2010;115(5):1063-70. https://doi.org/10.1016/j.ijsu.2011.09.004

18. Lara SR, Magaton AP, Cesar MB, Gabrielloni MC, Barbieri M. Experience of women in labor with the use of flowers essences. Rev Pesqui: Cuid Fundam. 2020;12:161-7. https://doi.org/10.9789/2175-5361.rpcfo.v12.7178

19. Oliveira CC. Understanding pain and human suffering. Rev Bioét. 2016;24(2):225-34. https://doi.org/10.1590/1983-80422016242122

20. Buckley SJ. Executive summary of hormonal physiology of childbearing: evidence and implications for women, babies, and maternity care. J Perinat Educ. 2015;24(3):145-53. https://doi.org/10.1891/1058-1243.24.3.145

21. Ahmad A, Srikantiah RM, Yadav C, Agarwal A, Manjrekar PA, Hegde A. Cord blood levels of insulin, cortisol and HOMA2-IR in very preterm, late preterm and term newborns. J Clin Diagn Res. 2016:10(5):BC05-8. https://doi.org/10.7860/JCDR/2016/18770.7857 